\title{
Le Marche in tavola: Realtà Virtuale e Realtà Aumentata per il patrimonio alimentare
}

\author{
Daniele Rossi
}

Abstract

II patrimonio enogastronomico locale costituisce un fattore fondamentale per la definizione dell'identità di un territorio, diventando, spesso, un indispensabile strumento di promozione e di attrazione turistica. Le tipicità enogastronomiche sono in genere impiegate per mettere a punto strategie di branding volte sia a ridefinire l'immagine di un territorio sia per iniziative nel settore del turismo esperienziale. Tuttavia, ad oggi, non risultano molti in questo campo i progetti che esplorano le potenzialità delle tecnologie di Realtà Virtuale (VR) e Aumentata (AR), per valorizzare l'enogastronomia locale in una chiave emozionale. II rapido e recente sviluppo di tali tecnologie e di diversi dispositivi connessi, le ha rese di grande attualità ma spesso relegate all'ambito dell'industria videoludica e dell'intrattenimento.

In questo quadro l'articolo vuole illustrare i presupposti e le prime attività di analisi di un progetto di ricerca finalizzato a coniugare la valorizzazione e la narrazione del patrimonio enogastronomico con le potenzialità di tali tecnologie, fruite sia tramite visori 3D, sia tramite la mediazione di un dispositivo. L'obiettivo che si propone la ricerca è duplice: da una parte indagare quali sono le potenzialità di VR e AR per valorizzare, documentare e promuovere la cultura del patrimonio enogastronomico dei territori della Regione Marche, dall'altra sperimentare nuove strategie di progettazione e nuove forme di comunicazione attraverso l'impiego di tecnologie innovative.

Parole chiave

Realtà Virtuale, Realtà Aumentata, patrimonio agroalimentare, digital storytelling, design per i territori.

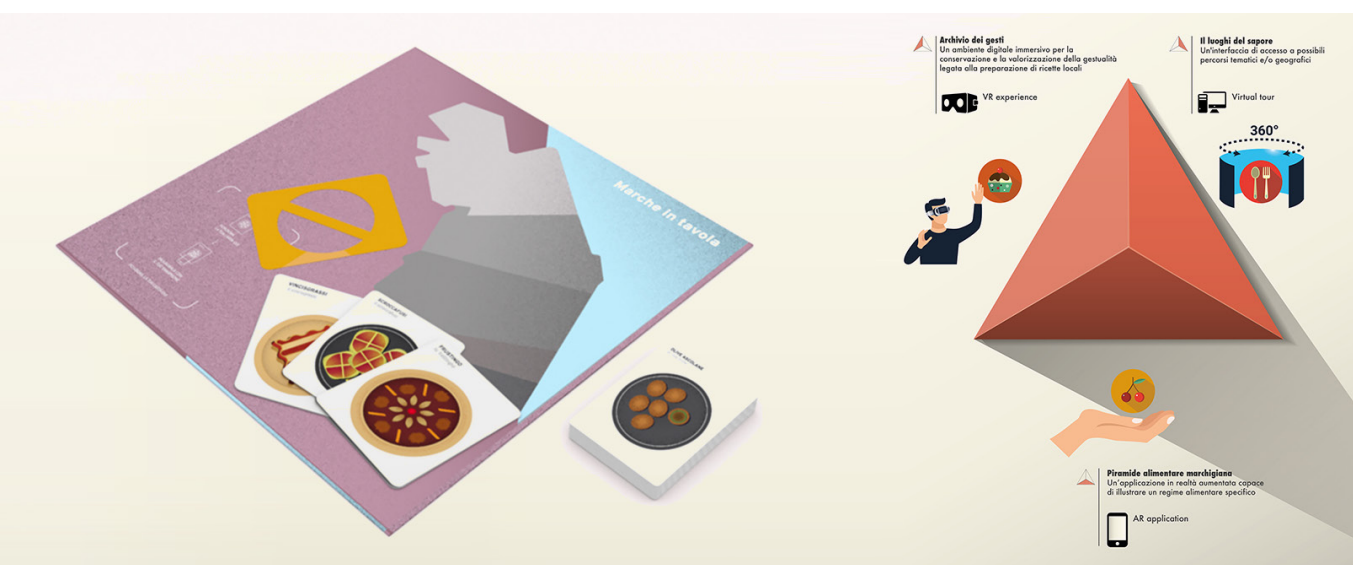




\section{Scenario: il cibo come patrimonio culturale delle Marche}

Secondo Massimo Montanari "i valori portanti del sistema alimentare non si definiscono in termini di 'naturalità' bensì come esito e rappresentazione di processi culturali che prevedono l'addomesticamento, la trasformazione, la reinterpretazione della Natura" [Montanari 2004, p. XI]. In questo senso Montanari ritiene il cibo una forma culturale, sia quando si produce, poiché l'uomo vuole creare il proprio cibo, sia quando si prepara, attraverso le pratiche della cucina, ma anche quando si consuma, perché gli alimenti sono scelti con criteri legati all'economia, ai valori nutrizionali e a quelli simbolici presenti nelle diverse culture. Pertanto, i prodotti enogastronomici tipici regionali possono essere intesi come parte "dell'identità umana e come uno dei più efficaci strumenti per comunicarla" [Montanari 2004, p. XII]. Nel tempo diversi studi hanno dimostrato che l'enogastronomia è il risultato di un sistema socioeconomico locale, costituito da risorse naturali e culturali [Graziani, Rizzi 20 I5; Allaire et al.

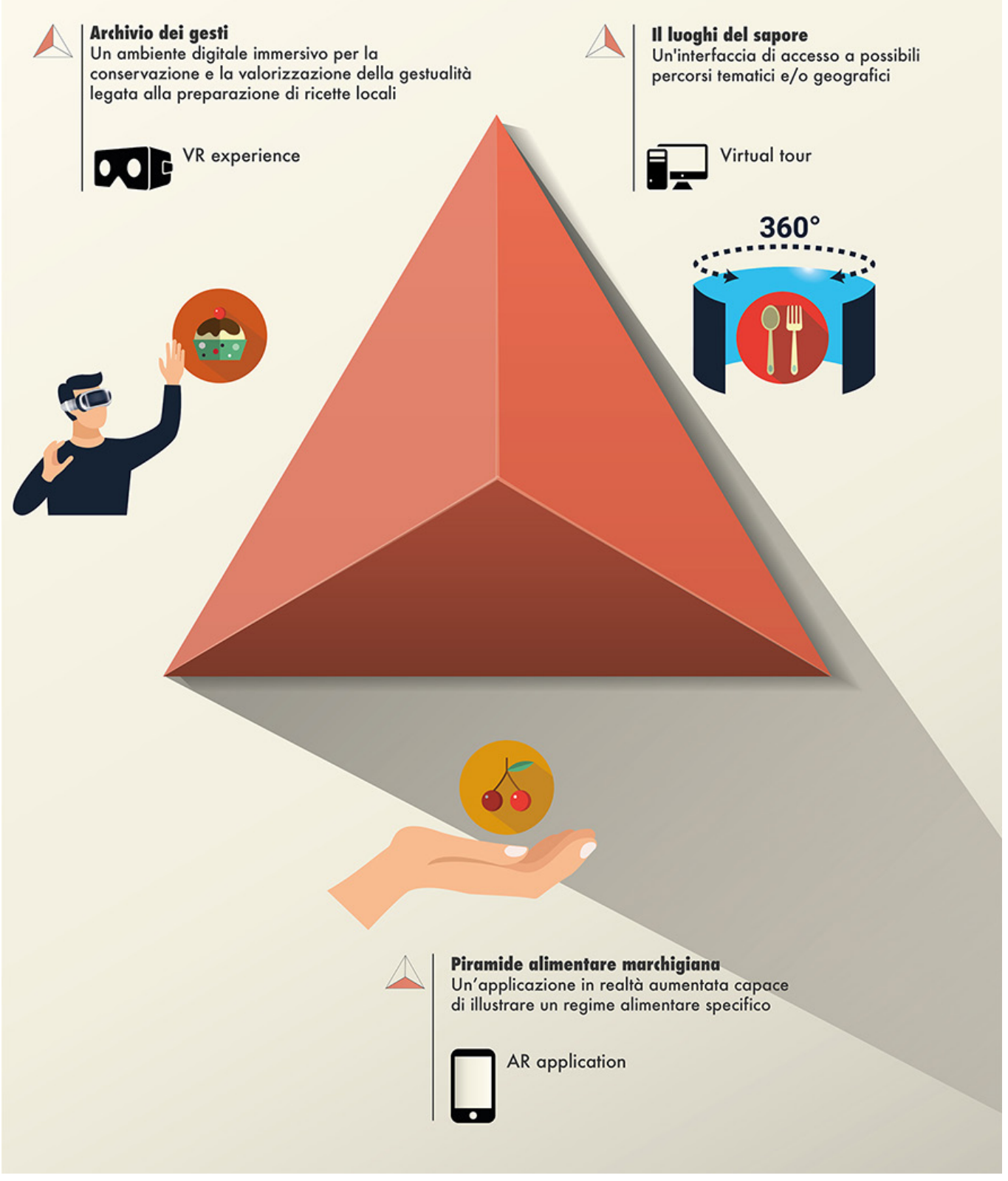


20 I I; Symbola 20 I5; Marsden, Sonnino, 20 I2]. Ciò appare particolarmente vero nei distretti agricoli come quelli marchigiani, dove l'eccellenza dei prodotti si basa su un mix di qualità della produzione (tradizioni manifatturiere e culinarie locali), del territorio e del paesaggio (patrimonio culturale, tutela dell'ambiente, ecc.) e della vita (relazioni umane, benessere ecc.). Le ricostruzioni delle vicende storiche della cucina marchigiana e delle sue tradizioni alimentari rivelano interessanti rapporti tra cultura popolare e aristocratica, laica e conventuale, ma anche tra tradizione orale e codificazioni scritte [Bellesi, Franca, Lucchetti 20 I0].

Tali rapporti sono testimoniati da una vasta documentazione che conferma come il territorio marchigiano già tra il IX al III secolo a.C. all'epoca dei Piceni e poi in età romana, sia conosciuto per le coltivazioni e i prodotti agricoli, tra i quali il grano, i frutti, il vino e le olive. Gran parte di questo patrimonio è stato tramandato attraverso le tradizioni locali e nelle diffuse

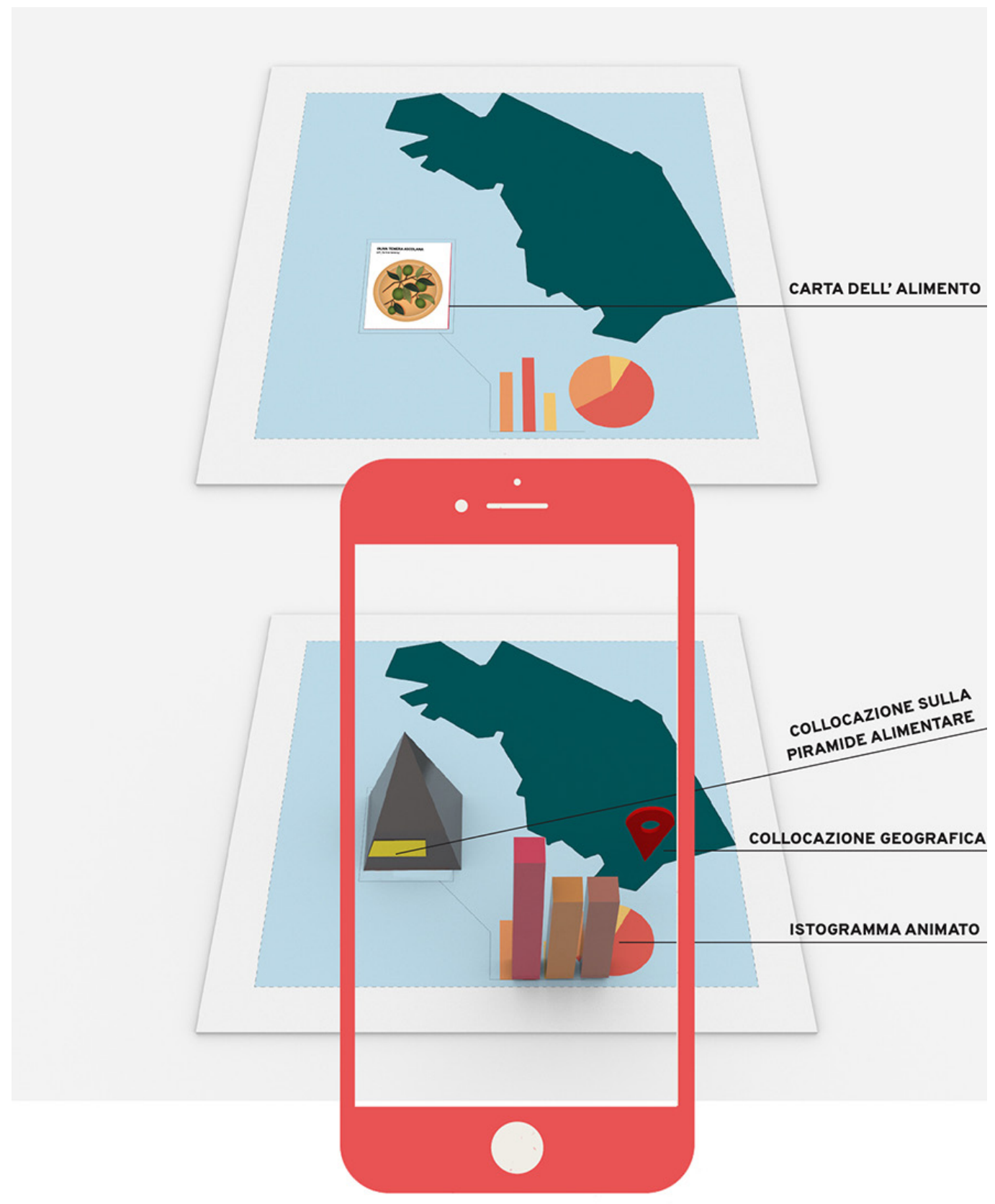


produzioni biologiche, oggi conosciute nel mondo per le eccellenze vinicole o per i primati nel campo oleario, apicolo e per l'alta qualità della ristorazione. Tuttavia, l'enogastronomia marchigiana rappresenta non soltanto un vettore economico, ma anche un importante fattore socioculturale, intimamente connesso a un complesso insieme di beni materiali, costituiti dal patrimonio architettonico, artistico, ambientale e paesaggistico, e immateriali rappresentati dalla cultura, l'identità dei luoghi, i modi di vivere e le tradizioni, ma anche dalle risorse umane e le capacità imprenditoriali [Simonelli, Zurlo 2004]. In sostanza i prodotti enogastronomici detengono un ruolo centrale nella costruzione del capitale territoriale e come tali possono anche diventare il brand di un'intera regione, come dimostrano i casi di Barolo/Langhe, Franciacorta o Chianti, ponendosi spesso al centro di specifiche strategie di branding volte a ridefinire l'immagine dei territori [Anholt 2007; Dioli, Rizzi 20 I0; Morgan et al. 2007] e delle attività del turismo esperienziale. Infatti, negli ultimi anni il grande sviluppo del turismo enogastronomico in Italia ha fatto leva sulla qualità delle produzioni tipiche, sulle tradizioni culinarie, sul paesaggio rurale, sull'ambiente e, più in generale, su una vasta gamma di attrattive naturali intangibili [Antonioli Corigliano 2004.

\section{II visual design e le tecnologie VR e AR per la valorizzazione del territorio}

Negli ultimi anni la ricerca progettuale in Italia si è spesso concentrata sulla valorizzazione e la comunicazione dei territori. A partire dagli anni ' 80 , diversi progetti si sono basati sul design come strumento metodologico in grado di valorizzare, raccontare e innovare il patrimonio culturale locale, materiale e immateriale [Campagnaro, Lupo 2009; Villari 20 I3, Parente, Sedini 2019]. Tali esperienze hanno dimostrato che il design può essere un importante volano per l'innovazione e lo sviluppo economico e sociale del capitale territoriale, attraverso la rigenerazione di culture, storie, risorse naturali e tradizioni locali. In particolare, in questi progetti il visual design appare in grado non solo di promuovere e valorizzare il patrimonio culturale locale, ma anche di sostenere e stimolare la capacità delle comunità locali di scoprire e riconoscere i potenziali beni territoriali per trasformarli in vere e proprie risorse [Manzini 2005; Manzini 20I5].

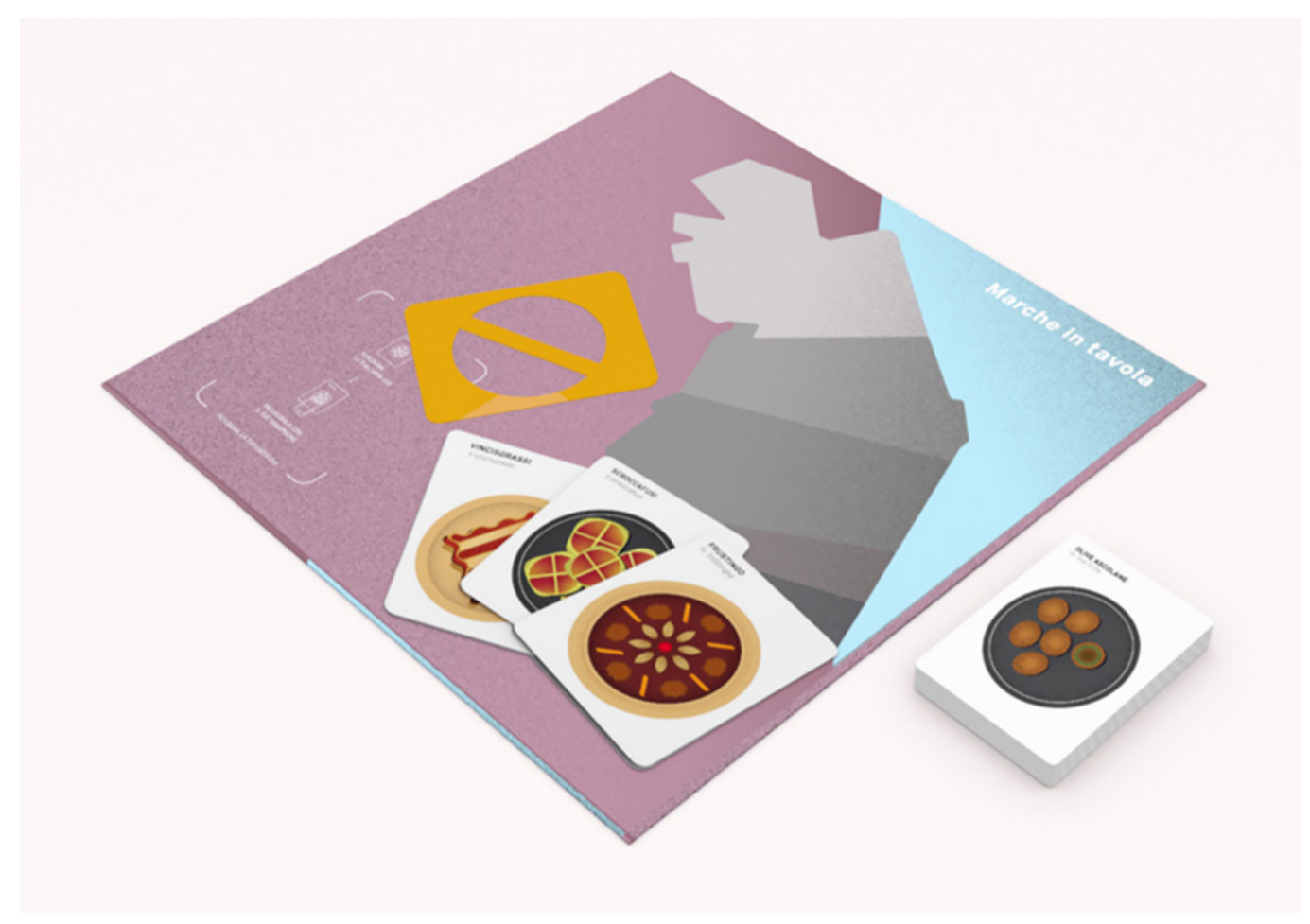


II visual design riveste inoltre un ruolo fondamentale, soprattutto nella creazione di strategie e strumenti narrativi, che possono essere impiegati sia nelle fasi analitiche ed esplorative sia per definire e realizzare diverse azioni e interventi di progetto. La valorizzazione territoriale può divenire ancora più efficace attraverso l'impiego di nuove tecnologie digitali che oggi stanno modificando radicalmente l'approccio alla conoscenza, trasformando la percezione dei siti culturali e del patrimonio culturale in ambienti interattivi, interconnessi e multimediali attraverso sistemi di realtà mista che consentono di esplorare, imparare, condividere e approfondire i loro contenuti. Queste recenti modalità esperienziali trovano i loro presupposti tecno-culturali intorno alla metà degli anni Settanta, quando Myron Krueger ( 1983) nel definire un tipo di esperienza digitale così coinvolgente da poter essere percepito come reale, elabora il termine Realtà Artificiale. Un concetto che Krueger impiega come strumento per esaminare le relazioni uomo-macchina, analizzando le possibili interfacce di scambio e le relazioni socioculturali ad essa associate. All'inizio degli anni Novanta, l'idea di Realtà Artificiale venne superata dal concetto di continuum Reale-Virtuale, sintetizzato da Paul Milgram [Milgram, Kishino 1994] attraverso un segmento ai cui estremi sono posti i termini 'Reale' e 'Virtuale', mentre nell'intervallo tra i due è individuata un'area che identifica tipi di realtà mista. In seguito, Milgram su questa base, ha costruito una tassonomia di sistemi visivi per ambienti in mixed reality, secondo il grado d'immersione richiesto e del dispositivo impiegato nell'esperienza. In sostanza se l'utente sperimenta una realtà in cui sono integrate delle informazioni digitali strutturate ci troviamo nel campo della Realtà Aumentata, o in quel campo della computer grafica che indaga la possibilità di sovrapporre alla realtà percepita delle elaborazioni digitali. Viceversa, se l'utente sperimenta una realtà totalmente digitale, dove l'informazione è strutturata per configurare il mondo percepito, allora siamo in presenza di quella che Jaron Lanier [1992] nei primi anni Ottanta ha definito Realtà Virtuale.

Fig. 4. Elaborazioni grafiche relative alle carte degli alimenti e delle ricette marchigiane (elaborazione grafica di Livia Barone).
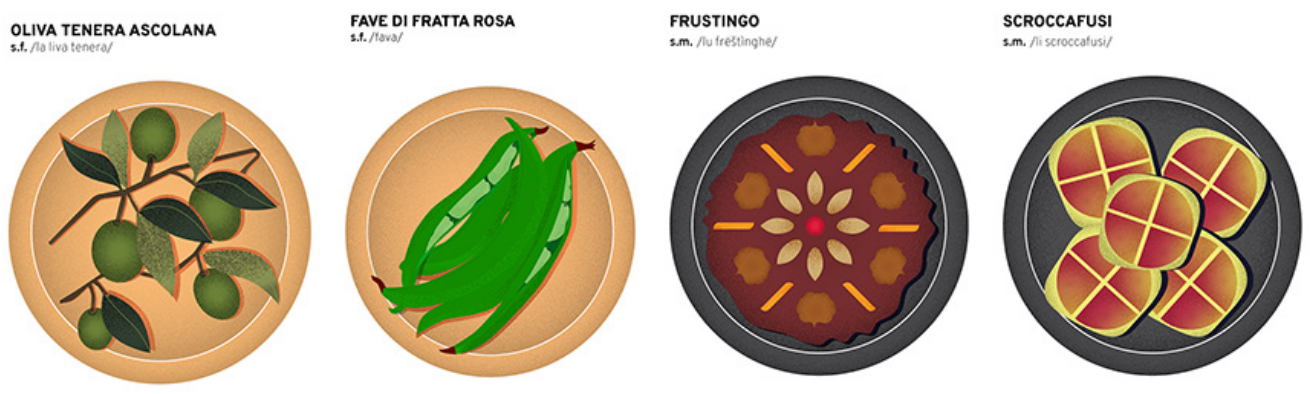

Oggi la realtà virtuale, aumentata, la realtà mista, i feedback tattili, i riconoscimenti dei gesti, ecc. sono tecnologie dai contorni sfumati, ma tuttavia possono essere raggruppate, come previsto da Krueger, sotto il termine di Realtà Artificiale o, come suggerisce Giuseppe Riva (2019), in Tecnologie della Confluenza. Tale accelerazione tecnologica ha favorito in ambito didattico e culturale lo sviluppo di tecniche di mediazione digitale, modelli grafici e tridimensionali, panorami a $360^{\circ}$, interfacce dinamiche, che stanno ridefinendo spazi e tempi di apprendimento, rendendo sempre più evidente come i nuovi 'media' si siano progressivamente spostati verso modelli di comunicazione che mirano ad un'estensione dei contenuti attraverso forme di accessibilità sempre più immediate. L'obiettivo di queste nuove forme di rappresentazione appare quello di rendere l'informazione più esplicita, facilitando la comprensione di concetti complessi mantenendo, tuttavia, inalterato il livello del contenuto scientifico. Si sono avviati, così, processi di apprendimento basati sulla 'storia' piuttosto che sul 'catalogo. Processi in cui dove è richiesta una partecipazione attiva degli utenti, fondati su narrazioni dinamiche e sull'idea che una storia con una sceneggiatura chiara sarà ricordata meglio di quella che non prende in considerazione tali fattori [Graesser, Nakamura 1982]. 
Tutto questo rivela come tecnologie sviluppate e impiegate per lo più per il gioco e l'intrattenimento riservano oggi notevoli potenzialità e possono essere utilizzate per contribuire attivamente alla valorizzazione dei diversi aspetti che caratterizzano i patrimoni culturali di un territorio, compresi quelli legati all'ecosistema agroalimentare.

Fig. 5. Prime sperimentazioni relative all'impasto su un piano di lavoro in cucina tracciate e registrate dal guanto Talking Hands sviluppato da Limix.
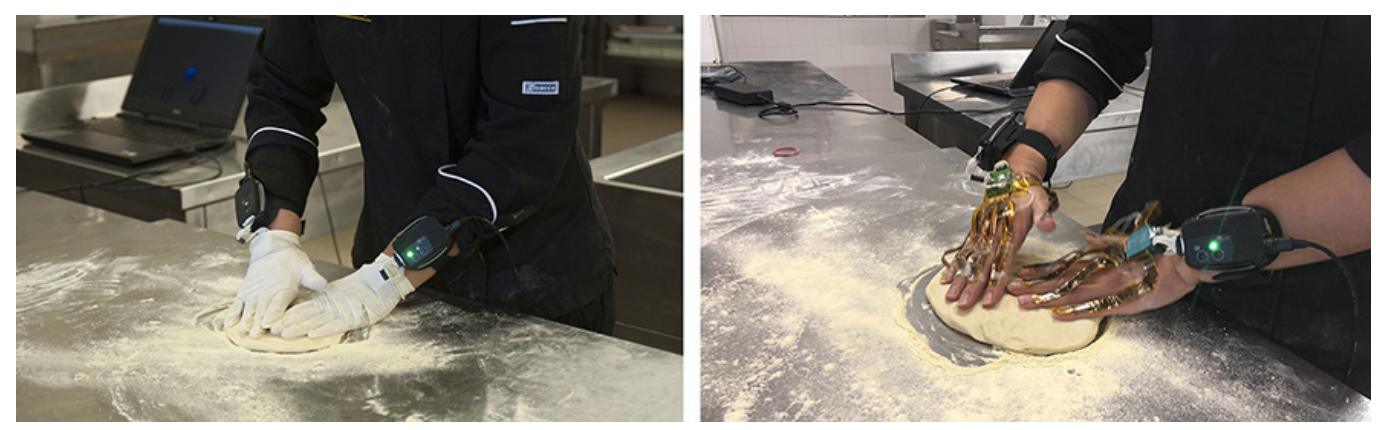

\section{Metodologia ed obiettivi della ricerca}

Come evidenziato in precedenza l'interesse per il patrimonio enogastronomico si coniuga con la storia e le tradizioni locali che conferiscono agli alimenti valori unici e inscindibili a quelli del territorio.

In tale scenario, è stata avviata una attività di ricerca e di progetto [I] che si pone l'idea di 'esperienza' come strumento per promuovere l'interesse del visitatore attraverso nuove forme di comunicazione e la costruzione di un universo narrativo in grado di coinvolgerlo e guidarlo verso la conoscenza della cultura enogastronomica del territorio marchigiano. Tale ricerca, quindi, si fonda sulla convinzione che attraverso il visual design e l'impiego delle tecnologie digitali AR e VR si possa giungere alla definizione di forme innovative di storytelling capaci di valorizzare i patrimoni enogastronomici locali e contribuire alla promozione della ricchezza culturale delle storie, delle tradizioni del saper fare, della qualità diffusa e del genius loci delle Marche.

Il disegno di tali esperienze, inteso come rappresentazione dei valori tangibili e intangibili legati al territorio può costituire una nuova modalità per preservare alcune caratteristiche precipue della regione, lontana dalle esperienze di visita 'sintetiche', che in genere trasformano i luoghi in mere attrazioni turistiche. Per tali motivi la ricerca mira in particolare a fornire strumenti innovativi basati su sistemi di realtà mista e dispositivi e applicazioni avanzate, in grado di diffondere la cultura enogastronomica marchigiana, raccontando storie e peculiarità dei prodotti tipici, delle materie prime e dell'industria alimentare, e come queste si coniugano con il patrimonio paesaggistico.

Si prevede quindi l'elaborazione di una precisa strategia narrativa basata su attività esperienziali, attraverso l'esplorazione di itinerari locali e la scoperta di prodotti enogastronomici di qualità [2].

I partecipanti al progetto di ricerca provengono da ambiti disciplinari differenti, a designer ed esperti di rappresentazione digitale si sono affiancati biologi, nutrizionisti, studiosi dell'alimentazione marchigiana ed informatici.

Nel loro insieme queste competenze sono complementari e si estendono dal visual design alla storia all'arte, dalla videografia ai rilievi paesaggistici, fino alla computer grafica, modellazione digitale 3D, comunicazione visiva, applicazioni interattive, gestione di database ecc.

II concept grafico capace di riassumere le attività progettuali proposte, è rappresentato una piramide a base triangolare che trae spunto, come è facile intuire, dai modelli grafici utilizzati per descrivere un regime alimentare (fig. I). 
Le tre facce della piramide raccontano di tre differenti artefatti multimediali che si differenziano per contenuti e per le tecnologie abilitanti.

II sistema di tali artefatti sarà composto da:

- Un sistema composto da un table board e cards da consultare mediante l'ausilio di un'applicazione in realtà aumentata da fruire mediante smartphone o tablet capace di illustrare in maniera interattiva una possibile piramide alimentare 'marchigiana' con l'intento di favorire la conoscenza delle qualità degli alimenti tipici della regione (in fase di realizzazione). Posizionando le carte, raffiguranti le singole tipicità, nell'apposito stallo presente sul tabellone contenente il profilo geografico delle Marche, ed inquadrandole con il proprio dispositivo, verranno visualizzate informazioni relative alla posizione che occupa l'alimento sulla piramide alimentare, un istogramma animato che mostra i valori nutrizionali ed in fine la città o il territorio di provenienza. Ad integrazione dell'esperienza, una serie di carte speciali dedicate ad alcune ricette tipiche, illustreranno con le medesime modalità come "correggere" la posizione sulla piramide, e di conseguenza la frequenza di utilizzo, modificando dosaggi o tipi di cottura (figg. 2-4).

- Un archivio digitale, da consultare in modalità immersiva, disegnato con l'obiettivo di documentare e tramandare l'arte della trasformazione dei prodotti e i saperi delle tradizioni culinarie marchigiane, mappando e catalogando le gestualità necessarie per la preparazione di alcuni alimenti tipici (in fase di realizzazione).

Tale sistema di archiviazione è stato avviato in collaborazione con l'Accademia Chefs di San Benedetto del Tronto e prevede l'impiego di speciali guanti, ideati e brevettati dallo Spin-off Limix [3] di Unicam, capaci di registrare i movimenti delle mani e degli avambracci e tracciarli in uno spazio 3D (figg. 5, 6).

Fig. 6. Confronto tra i movimenti necessar all'impasto (sopra) e corrispondente digitale visualizzato mediante rigging su modello 3D (sotto).
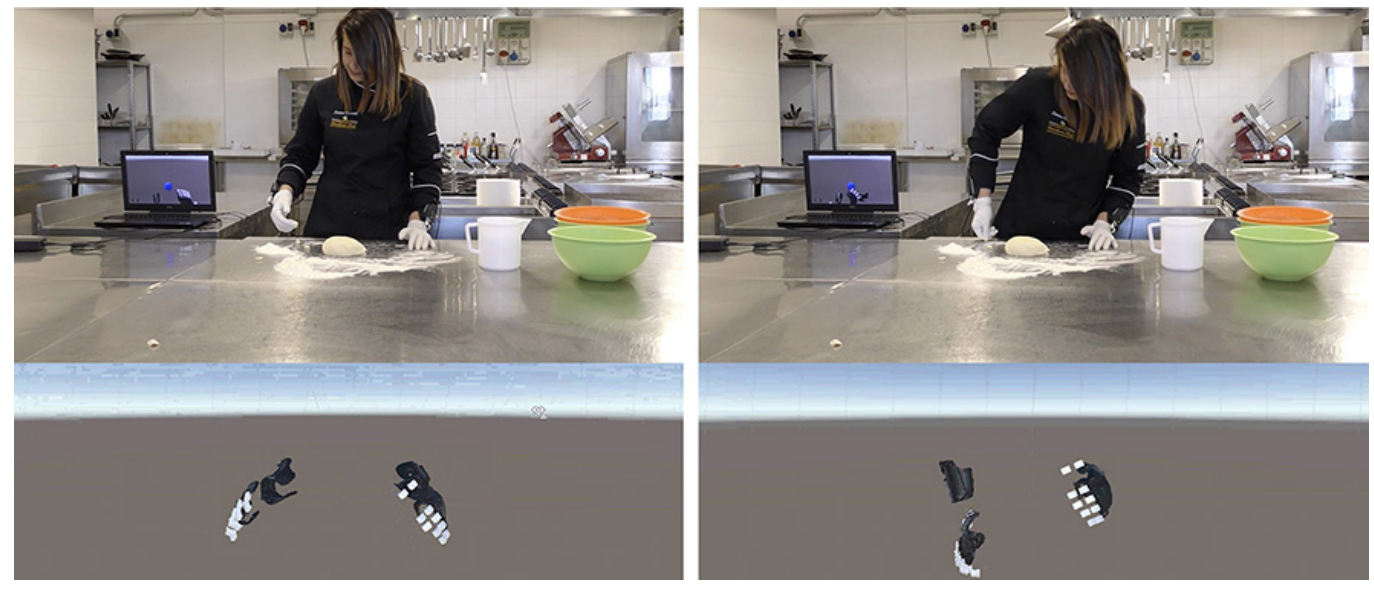

Dopo una prima fase di verifica, tutt'ora in corso, con alcuni cuochi professionisti, l'obiettivo sarà quello di far indossare i guanti, e quindi tracciare i movimenti delle mani e delle dita, delle cosiddette vergare marchigiane, ovvero le anziane donne che avevano in mano la vita domestica e che sono custodi delle tradizioni fondate sull'esperienza.

L'esperienza VR, fruibile in realtà virtuale immersiva sarà integrata da documenti, foto, video-interviste, ricettari e riproduzioni tridimensionali delle stoviglie necessarie per la preparazione.

- Un tour virtuale costruito mediante panorami sferici collegati ed interagibili, capace di raccontare fotograficamente il territorio marchigiano e i luoghi della produzione in relazione agli ingredienti e alle ricette prese in esame (da realizzare). 


\section{Conclusioni}

Le peculiarità del paesaggio marchigiano saranno illustrate in termini di patrimonio enogastronomico, attraverso dispositivi e applicazioni che si collocano nel mezzo del continuum Reale-Virtuale e che percorrono diversi livelli di immersione.

Negli ultimi anni l'opportunità di vivere esperienze immersive, di realtà virtuale o realtà aumentata, si è ampliata al punto da essere considerata alla portata di tutti.

Le VR experience nel settore turistico oggi sembrano offrire strategie promozionali per arricchire e innovare le tradizionali modalità di valorizzazione digitale di un territorio (siti web, mobile apps, social media, ...). In tale cornice operativa, il progetto di ricerca descritto in questo articolo intende rappresentare un esperimento pilota nell'impiego delle tecnologie VR e AR per la valorizzazione delle eccellenze nel settore agroalimentare ed enogastronomico della regione Marche.

L'obiettivo è fornire informazioni storico-culturali, mediate da applicazioni digitali 3D, per mezzo di strumenti tecnologicamente avanzati basati su sistemi di mixed reality per raccontare e diffondere la varietà dellindustria alimentare e la sua storia legata al territorio di origine.

\section{Note}

[I] Progetto finanziato nell'ambito del bando istituito dall'Università di Camerino per l'attribuzione del Fondo di Ateneo (FAR) 2018. Durata: 24 mesi $(1 / 2 / 2019-1 / 2 / 2021)$.

[2] A titolo esemplificativo: le olive all'ascolana, la mela rosa dei Sibillini, il miele dei monti azzurri, formaggi di Fossa, il salame di Fabriano, la pecora sopravvissana, il ciauscolo dell'alta marca, la crescia fogliata di Fiuminata, il torrone di Camerino, il salame di fichi marchigiano, il verdicchio di Matelica, la Vernaccia di Serrapetrona, il vino cotto di Loro Piceno, la pesca della Valdaso, il pesce dell'adriatico, i vincisgrassi, il carciofo di Monte Lupone.

[3] LiMiX Srl è uno spin off dell'Università di Camerino che lavora nella ricerca tecnologica, con particolare attenzione all'ambito del riconoscimento gestuale con il guanto Talking Hands: <http://www.limix.it/>.

\section{Riferimenti bibliografici}

Allaire Gilles, Casabianca François, Thevenod-Mottet Erik (20 I I). Geographical origin: a complex feature of agro food products. In Barham Elizabeth, Sylvander Bertil. Labels of origin for food: local development, global recognition. Cambridge: CABI International, pp. I- 12.

Anholt Simon (2007). Competitive Identity: The New Brand Management for Nations, Cities and Regions. London: Palgrave Macmillan.

Antonioli Corigliano M. (a cura di). (2004). Osservatorio internazionale sul turismo enogastronomico. Milano: Franco Angeli.

Bellesi Ugo, Franca Ettore, Lucchetti Tommaso (2010). Storia dell'alimentazione della cultura gastronomica e dell'arte conviviale nelle Marche. Ancona: II Lavoro Editoriale.

Campagnaro Cristian, Lupo Eleonora (a cura di). (2009). International Summer School. Designing Connected Places. Milano: Editrice Compositori.

Dioli llaria, Rizzi Paolo (20 I0). Strategic Planning and Place Marketing: the Italian Case. In Journal of Town \& City Management, I (3), pp.?|-2।.

Graesser A. C., Nakamura G.V. (1982). The impact of a schema on comprehension and memory. In Psychology of learning and motivation, 16, pp. 59-109. Academic Press.

Krueger Myron W. (1983). Artificial Reality. Boston: Addison-Wesley.

Lanier Jaron (1992).Virtual reality:The promise of the future. In Interactive Learning International, 8 (4), pp. $275-279$.

Manzini Ezio (2005). Enabling solutions for creative communities. In Designmatters, I0, pp. 64-68.

Manzini Ezio (2015). Design, when everybody designs: An introduction to design for social innovation. Cambridge: MA: MIT Press.

Marsden Terry K., Sonnino Roberta (2012). Human Health and Wellbeing and the Sustainability of Urban-Regional Food Systems, Current Opinion. In Environmental Sustainability, 4(4), pp. 427-430.

Milgram Paul, Kishino Fumio (1994). A taxonomy of mixed reality visual displays. In IEICE TRANSACTIONS on Information and Systems, 77(12), pp. I321-1329. 
Montanari Massimo (2004). Il cibo come cultura. Bari: Laterza.

Morgan Nigel, Pritchard Annette, Pride Roger (a cura di). (2007). Destination branding. Oxford: Elsevier Butterworth-Heinemann. Parente Marina, Sedini Carla (a cura di). (2019). D4T design per i territori.Approcci, metodi, esperienze. Trento: List. Riva Giuseppe (2019). Realtà Virtuali. Firenze: Giunti.

Simonelli Giuliano, Zurlo Francesco (2003). MEDesign Research. Exploiting resources in the Meditrerranean area: what is the role of design? In AA.W. Designing Designers: Design for a local global world. Milano: POLI.design, pp 89- I0 I.

Villari Beatrice (2013). Design, comunità, territori. Un approccio community centred per progettare relazioni, strategie e servizi. Milano: Libraccio Editore.

Autore

Daniele Rossi, Università degli Studi di Camerino, daniele.rossi@unicam.it

Per citare questo capitolo: Rossi Daniele (2020). Le Marche in tavola: Realtà Virtuale e Realtà Aumentata per il patrimonio alimentare/Le Marche in tavola: Virtual and Augmented Reality for food heritage. In Arena A., Arena M., Brandolino R.G., Colistra D., Ginex G., Mediati D., Nucifora S. Raffa P. (a cura di). Connettere. Un disegno per annodare e tessere. Atti del $42^{\circ}$ Convegno Internazionale dei Docenti delle Discipline della Rappresentazione/Connecting. Drawing for weaving relationships. Proceedings of the 42th International Conference of Representation Disciplines Teachers. Milano: FrancoAngeli, pp. 3756-3773. 


\title{
Le Marche in Tavola: Virtual and Augmented Reality for Food Heritage
}

\author{
Daniele Rossi
}

\section{Abstract}

The local wine and food heritage is a crucial element of the identity of a territory and often becomes a crucial theme in tourism promotion. Typical food and wine products are used both to develop branding strategies aimed at redefining the image of a territory and to launch initiatives in the field of experiential tourism.

However, so far there are not many projects that explore the potential of Virtual Reality (VR) and Augmented Reality (AR) technologies in this field. Recently, the rapid development of devices that allow the use of Mixed Reality (VR and AR) has made these technologies - which have been known for decades but have always been relegated to the experimental field of technological and media research- very topical.

In this framework, the article aims to illustrate the assumptions and the first analysis activities of a research project aimed at combining the enhancement and narration of the food and wine heritage with the potential of these technologies, used both through 3D viewers and through the mediation of a device.

The purpose of the research is twofold: to investigate, in general, what are the potential of $\bigvee R$ and AR to enhance and promote the richness of the Marche Region' territory in terms of wine and food heritage; experiment with new design strategies and new forms of communication through the use of cutting edge technology.

Keywords

Virtual Reality, Augmented Reality, digitale storytelling, visual design.

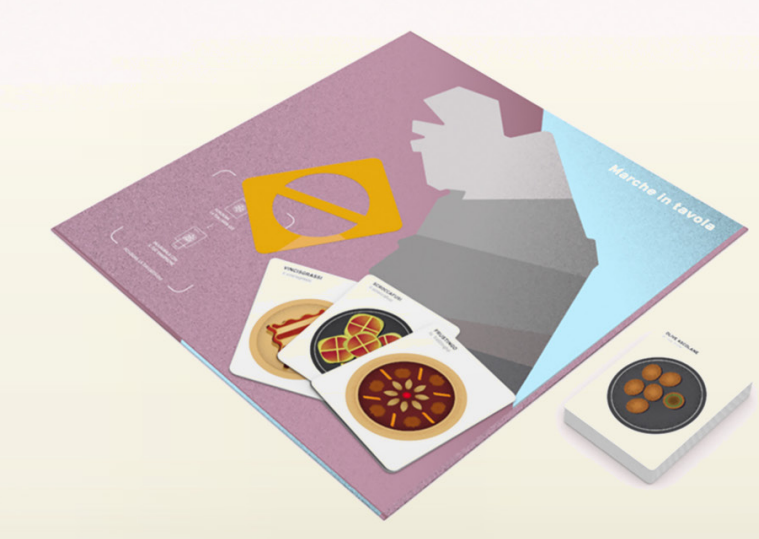

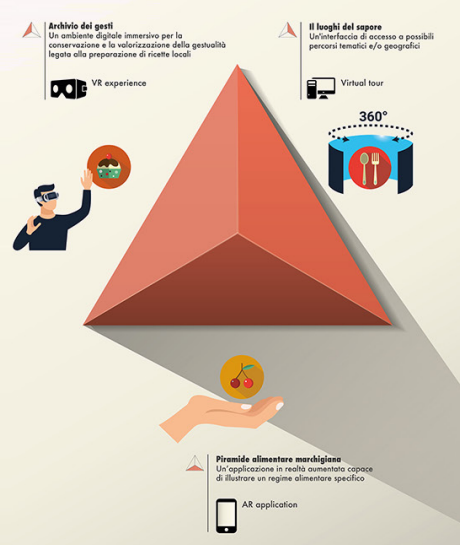




\section{Scenario: food as a cultural heritage of the Marche region}

According to Massimo Montanari "the core values of the food system are not defined in terms of 'naturalness' but as the outcome and representation of cultural processes that involve the domestication, transformation and reinterpretation of Nature" [Montanari 2004, p. XI]. In this sense Montanari considers food a cultural form, both when it is produced, since man wants to create his own food, and when it is prepared, through the practices of cooking, but also when it is consumed, because food is chosen according to criteria linked to the economy, nutritional values and symbolic values present in different cultures.

Therefore, typical regional food and wine products can be understood as part of "human identity and one of the most effective tools to communicate it" [Montanari 2004, p. XII]. Over time, several studies have shown that food and wine is the result of a local socio-economic system, consisting of natural and cultural resources [Graziani, Rizzi 20I5; Allaire et al.

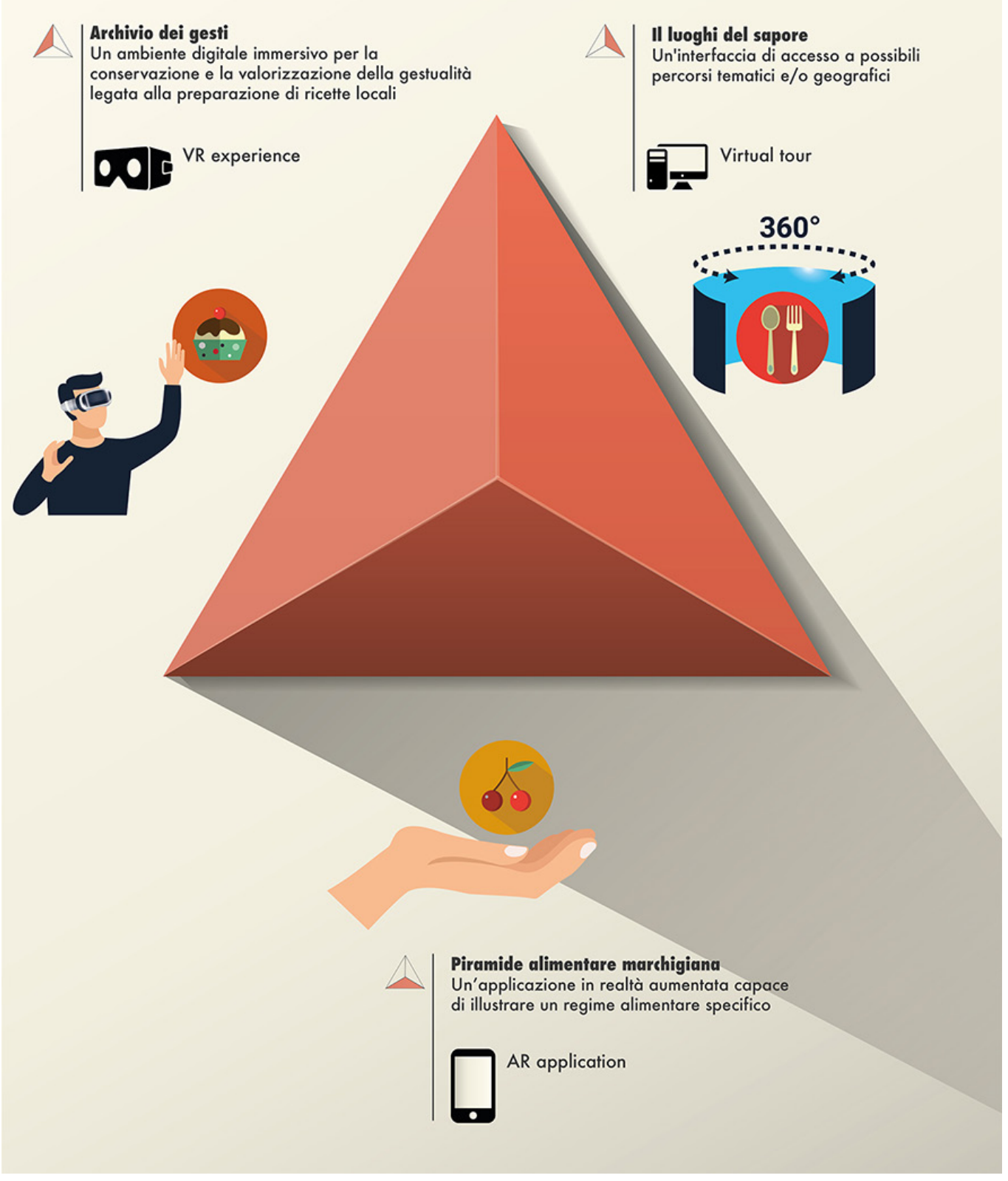


$201 \mathrm{I}$; Symbola 20 I5; Marsden, Sonnino 20 I2]. This is particularly true in agricultural districts such as those in the Marche region, where the excellence of products is based on a mix of quality of production (local manufacturing and culinary traditions), territory and landscape (cultural heritage, environmental protection etc.) and life (human relations, well-being etc.). The reconstructions of the historical events of Marche cuisine and its food traditions reveal interesting relationships between popular and aristocratic, secular and convent culture, but also between oral tradition and written codifications [Bellesi, Franca, Lucchetti 20 I0]. These relationships are testified by a vast documentation that confirms that the territory of the Marche region already between the 9th and 3rd centuries B.C. at the time of the Piceni and then in Roman times, is known for its crops and agricultural products, including wheat, fruits, wine and olives. Much of this heritage has been handed down through local traditions and widespread organic production, now known worldwide for its excellent wines or primates in the olive oil, beekeeping and high-quality food.

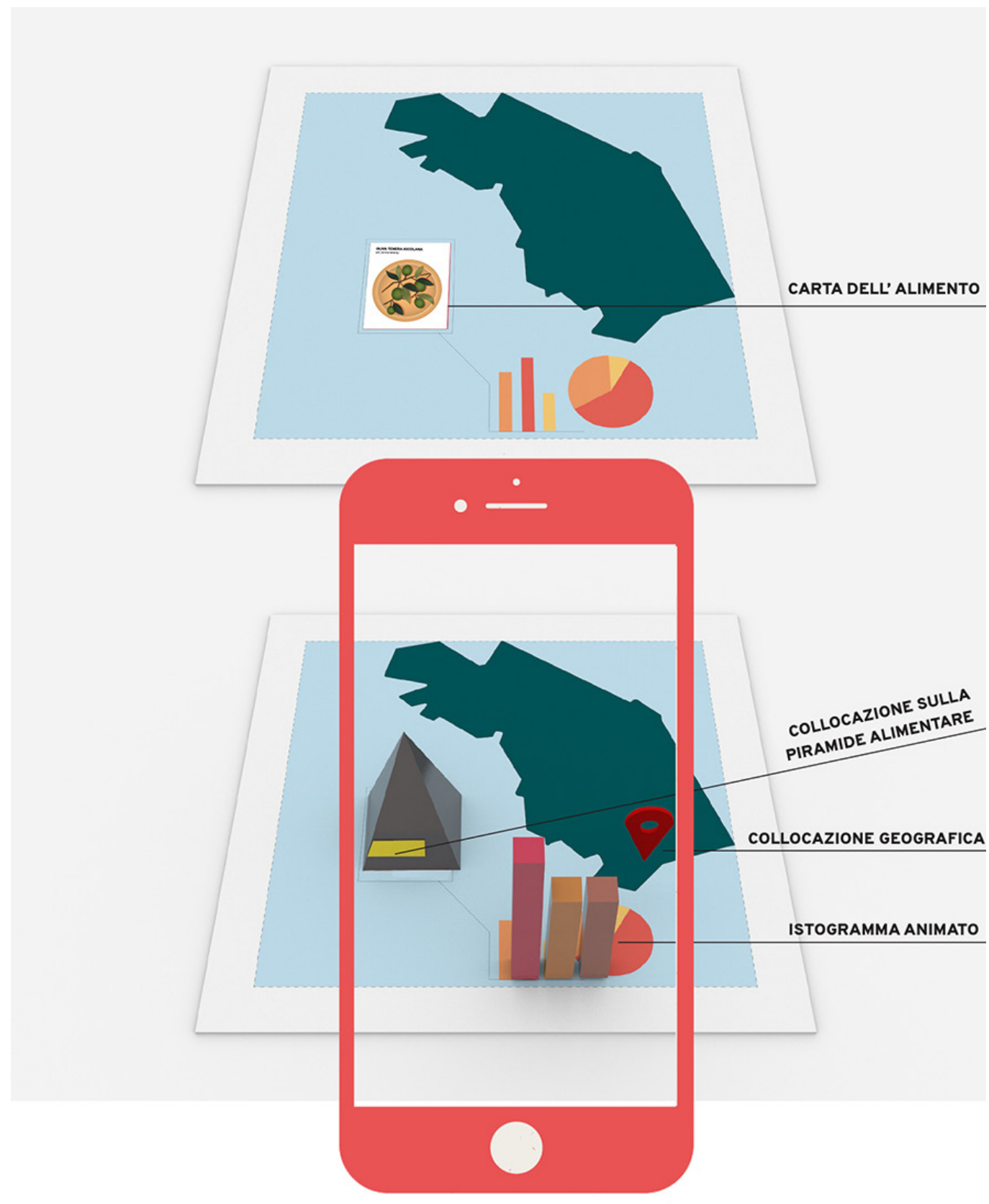

examination will be 
However, the gastronomy of the Marche region represents not only an economic vector, but also an important socio-cultural factor, intimately connected to a complex set of material goods, made up of the architectural, artistic, environmental and landscape heritage, and intangible assets represented by culture, the identity of places, ways of life and traditions, but also human resources and entrepreneurial skills [Simonelli, Zurlo 2004]. In essence, food and wine products play a central role in the construction of the territorial capital and as such can also become the brand of an entire region, as demonstrated by the cases of Barolo/Langhe, Franciacorta or Chianti, often placing themselves at the centre of specific branding strategies aimed at redefining the image of the territories [Anholt 2007, Dioli, Rizzi 20 I 0; Morgan et al. 2007] and of experiential tourism activities. In fact, in the last few years the great development of food and wine tourism in Italy has been based on the quality of typical products, culinary traditions, the rural landscape, the environment and, more generally, a wide range of intangible natural attractions [Antonioli, Corigliano 2004].

\section{Visual design and $V R$ and $A R$ technologies for the valorisation of the territory}

In recent years design research in Italy has often focused on the enhancement and communication of the territories. Since the 1980s, several projects have been based on design as a methodological tool able to enhance, narrate and innovate the local cultural heritage, both material and immaterial [Campagnaro, Lupo 2009; Villari 20 I3, Parente, Sedini 2019]. These experiences have shown that design can be an important driver for innovation and economic and social development of the territorial capital, through the regeneration of cultures, stories, natural resources and local traditions. In particular, in these projects visual design appears to be able not only to promote and enhance the local cultural heritage, but also to support and stimulate the ability of local communities to discover and recognize potential territorial assets to transform them into real resources [Manzini 2005; Manzini 20 I5].

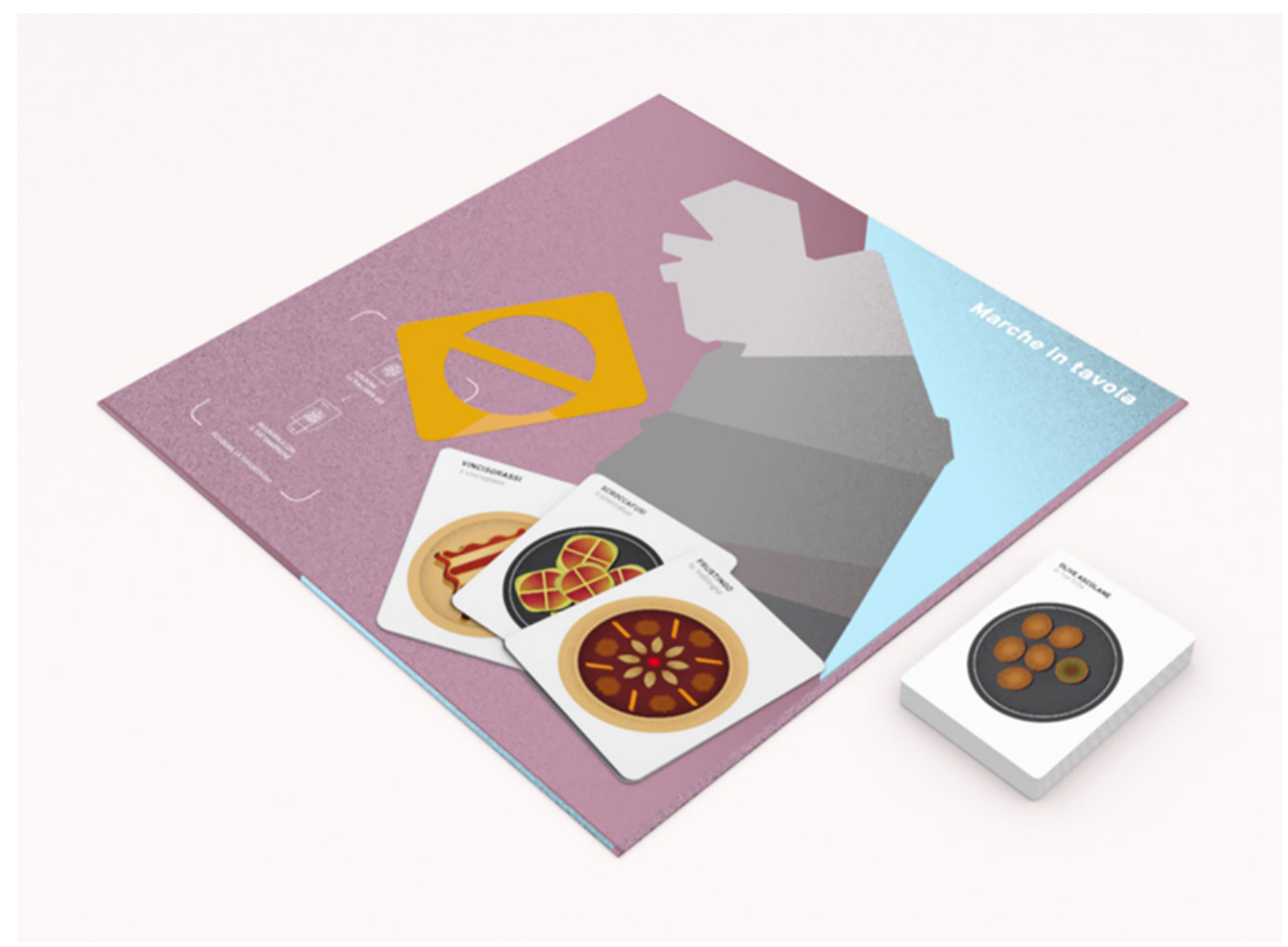


Visual design also plays a fundamental role, especially in the creation of strategies and narrative tools, which can be used both in the analytical and exploratory phases and to define and implement different actions and project interventions. Territorial valorization can become even more effective through the use of new digital technologies that today are radically changing the approach to knowledge, transforming the perception of cultural sites and cultural heritage into interactive, interconnected and multimedia environments through mixed reality systems that allow to explore, learn, share and deepen their contents.

These recent experiential modes found their techno-cultural premises around the mid-seventies, when Myron Krueger (1983), in defining a type of digital experience so engaging that it could be perceived as real, elaborated the term Artificial Reality. A concept that Krueger uses as a tool to examine man-machine relations, analyzing the possible interfaces of exchange and the socio-cultural relations associated with it. At the beginning of the $\mathrm{Ni}$ neties, the idea of Artificial Reality was surpassed by the concept of Real-Virtual Continuum, synthesized by Paul Milgram [Milgram, Kishino 1994] through a segment at the extremes of which are placed the terms Real and Virtual, while in the interval between the two is identified an area that identifies types of mixed reality.

Then Milgram built a taxonomy of visual systems for Mixed Reality environments, according to the degree of immersion required and the device used in the experience. Basically, if the user experiences a reality in which structured digital information is integrated, we find ourselves in the field of Augmented Reality, or in that field of computer graphics that investigates the possibility of superimposing digital elaborations on the perceived reality.Vice versa, if the user experiences a totally digital reality, where information is structured to configure the perceived world, then we are in the presence of what Jaron Lanier [1992] in the early eighties called Virtual Reality. Today, virtual reality, augmented reality, mixed reality, tactile feedback, gesture recognition, etc., are technologies with blurred contours, but nevertheless they can be grouped, as Krueger predicted, under the term Artificial Reality or, as Giuseppe Riva [2019] suggests, in technologies of confluence.

Fig. 4. Graphic elaborations related to the maps of food and recipes of the Marche region (graphic elaboration by Livia Barone)
OLIVA TENERA ASCOLANA

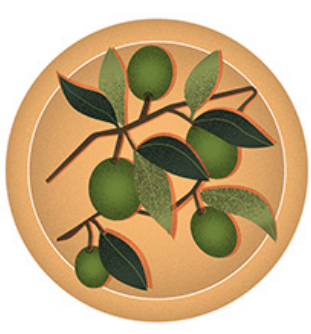

FAVE DI FRATTA ROSA
s.t. $/$ Sora/

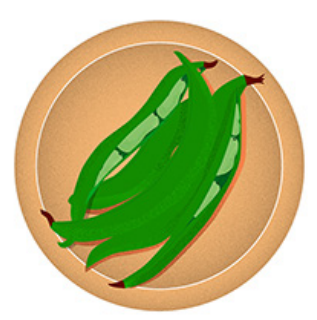

FRUSTINGO

s.m. /lutrestinghe/

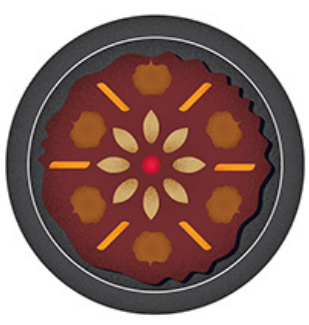

SCROCCAFUSI

sm. /iscroccatusi:

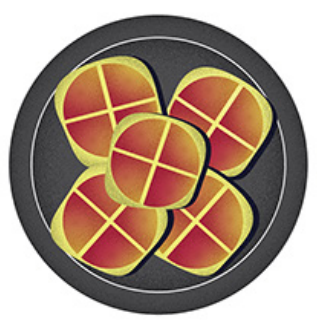

In the educational field, this technological acceleration has favoured the development of digital mediation techniques, graphic and three-dimensional models, $360^{\circ}$ panoramas, dynamic interfaces, which are redefining learning spaces and times, making it increasingly evident how the new 'media' have progressively shifted towards communication models that aim to extend content through increasingly immediate forms of accessibility. The objective of these new forms of representation appears to be to make information more explicit, facilitating the understanding of complex concepts while maintaining, however, the level of scientific content unchanged. Thus, learning processes based on 'history' rather than 'catalogue' have been initiated. 
Fig. 5. First experiments related to the doug on a kitchen worktop traced and recorded by the Talking Hands glove
Procedures where active user participation is required, based on dynamic narratives and the idea that a story with a clear script will be better remembered than one that does not take these factors into account [Graesser, Nakamura 1982]. All this reveals how technologies developed and used mostly for gaming and entertainment today have considerable potential and can be used to actively contribute to the enhancement of the different aspects that characterize the cultural heritage of a territory, including those related to the agro-food ecosystem.
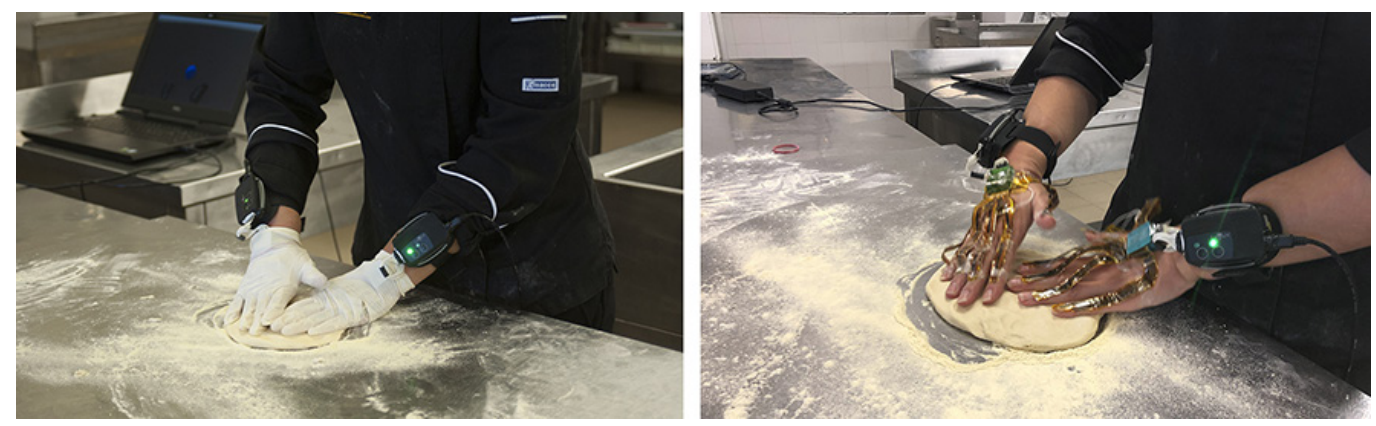

\section{Research methodology and objectives}

As pointed out above, interest in the food and wine heritage is combined with local history and traditions that give food values that are unique and inseparable from those of the territory.

In such a scenario, a research activity [I] has been launched, with the idea of "experience" as a tool to promote the visitor's interest through new forms of communication and the construction of a narrative universe able to involve him/her and guide him/her towards the knowledge of the food and wine culture of the Marche region. This research, therefore, is based on the conviction that through visual design and the use of AR and VR digital technologies it is possible to define innovative forms of storytelling capable of enhancing the local food and wine heritage and contributing to the promotion of the cultural richness of the stories, the traditions of know-how, the widespread quality and genius loci of the Marche region.

The design of such experiences, intended as a representation of the tangible and intangible values linked to the territory, may constitute a new way to preserve some of the region's main characteristics, far from the 'synthetic' experiences of visiting, which generally turn places into mere tourist attractions. For these reasons the research aims in particular to provide innovative tools based on mixed reality systems and advanced devices and applications, able to spread the food and wine culture of the Marche region, telling stories and peculiarities of typical products, raw materials and food industry, and how these are combined with the landscape heritage.

A precise narrative strategy based on experiential activities will be developed through the exploration of local itineraries and the discovery of quality food and wine products [2].

The participants in the research project come from different disciplinary backgrounds, and designers and experts in digital representation have been joined by biologists, nutritionists, food scholars from the Marche region and computer scientists.

Taken as a whole, these skills are complementary and extend from visual design to history to art, from videography to landscape surveys, to computer graphics, 3D digital modeling, visual communication, interactive applications, database management etc.

The graphic concept able to summarize the proposed design activities, is represented by a triangular-based pyramid that takes its cue, as it is easy to guess, from the graphic models used to describe a diet (fig. I). 
The three faces of the pyramid tell of three different multimedia artifacts that differ in content and enabling technologies.

The system of such artifacts will consist of:

- A system consisting of a table board and cards to be consulted with the aid of an augmented reality application to be used via smartphone or tablet capable of illustrating in an interactive way a possible "Marche" food pyramid with the intent to promote knowledge of the quality of food typical of the region. By placing the maps, depicting the individual typicality, in the special stall on the board containing the geographical profile of the Marche region, and framing them with your device, you will see information about the position that the food occupies on the food pyramid, an animated histogram that shows the nutritional values and finally the city or territory of origin. In addition to the experience, a series of special charts dedicated to some typical recipes, will illustrate in the same way how to 'correct' the position on the pyramid, and consequently the frequency of use, modifying dosages or types of cooking (figs. 2-4).

- A digital archive, to be consulted in an immersive way, designed with the aim of documenting and handing down the art of product transformation and the knowledge of the culinary traditions of the Marche region, mapping and cataloguing the gestures necessary for the preparation of some typical foods (under construction).

This filing system was started in collaboration with the Chefs Academy of San Benedetto del Tronto and involves the use of special gloves, designed and patented by university Spin-off Limix [3], capable of recording the movements of hands and forearms and tracing them in a 3D space (figs. 5, 6).

After a first phase of verification, still in progress, with some professional cooks, the objective will be to make the gloves wear, and then track the movements of hands and fingers, of the so called 'vergare marchigiane', i.e. the old women who had the home life in their hands and who are custodians of the traditions based on experience.

Fig. 6. Comparison between the movements necessary for the dough (above) and the digital corresponding displayed by rigging on $3 \mathrm{D}$ model (below).
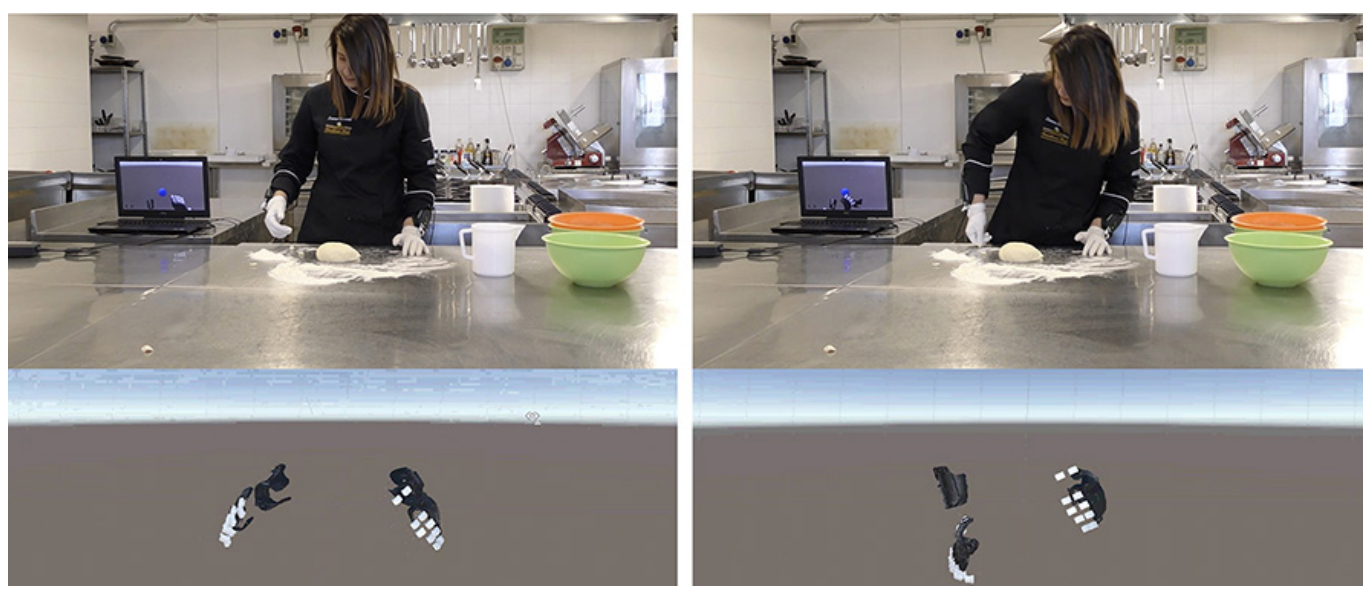

The VR experience, usable in immersive virtual reality, will be complemented by documents, photos, video interviews, cookbooks and three-dimensional reproductions of the dishes needed for the preparation.

- A virtual tour built by means of spherical panoramas connected and interacting, able to photographically tell the territory of the Marche region and the places of production in relation to the ingredients and recipes examined. 


\section{Conclusions}

The peculiarities of the Marche landscape will be illustrated in terms of food and wine heritage, through devices and applications that are located in the middle of the Real-Virtual continuum and that cover different levels of immersion.

In recent years the opportunity to live immersive experiences, virtual reality or augmented reality, has expanded to the point of being considered within everyone's reach.

VR experiences in the tourism sector today seem to offer promotional strategies to enrich and innovate the traditional ways of digital enhancement of a territory (websites, mobile apps, social media, ...). Within this operational framework, the research project described in this article aims to represent a pilot experiment in the use of VR and AR technologies for the enhancement of excellence in the food and wine sector of the Marche region.

The aim is to provide historical-cultural information, mediated by 3D digital applications, by means of technologically advanced tools based on mixed reality systems to tell and spread the variety of the food industry and its history linked to the territory of origin.

\section{Notes}

[I] Project funded under the call for proposals established by the University of Camerino for the award of the Fondo di Ateneo (FAR) 2018. Duration: 24 months (I/2/2019-1/2/202I).

[2] i.e.: le olive all'ascolana, la mela rosa dei Sibillini, il miele dei monti azzurri, formaggi di Fossa, il salame di Fabriano, la pecora sopravvissana, il ciauscolo dell'alta marca, la crescia fogliata di Fiuminata, il torrone di Camerino, il salame di fichi marchigiano, il verdicchio di Matelica, la Vernaccia di Serrapetrona, il vino cotto di Loro Piceno, la pesca della Valdaso, il pesce dell'adriatico, i vincisgrassi, il carciofo di Monte Lupone.

[3] LiMiX Srl is a spin-off of the University of Camerino which works in technological research, with particular attention to the field of gestural recognition with the glove called Talking Hands: <http://www.limix.it/>.

\section{References}

Allaire Gilles, Casabianca François, Thevenod-Mottet Erik (20 I I). Geographical origin: a complex feature of agro food products. In Barham Elizabeth, Sylvander Bertil. Labels of origin for food: local development, global recognition. Cambridge: CABI International, pp. I- I2.

Anholt Simon (2007). Competitive Identity: The New Brand Management for Nations, Cities and Regions. London: Palgrave Macmillan.

Antonioli Corigliano M. (a cura di). (2004). Osservatorio internazionale sul turismo enogastronomico. Milano: Franco Angeli.

Bellesi Ugo, Franca Ettore, Lucchetti Tommaso (20 I0). Storia dell'alimentazione della cultura gastronomica e dell'arte conviviale nelle Marche. Ancona: II Lavoro Editoriale.

Campagnaro Cristian, Lupo Eleonora (a cura di). (2009). International Summer School. Designing Connected Places. Milano: Editrice Compositori.

Dioli llaria, Rizzi Paolo (20 I0). Strategic Planning and Place Marketing: the Italian Case. In Journal of Town \& City Management, I(3), pp. ? I-2I.

Graesser A. C., Nakamura G.V. (1982). The impact of a schema on comprehension and memory. In Psychology of learning and motivation, 16, pp. 59- 109. Academic Press.

Krueger Myron W. (1983). Artificial Reality. Boston: Addison-Wesley.

Lanier Jaron (1992). Virtual reality: The promise of the future. In Interactive Learning International, 8 (4), pp. $275-279$.

Manzini Ezio (2005). Enabling solutions for creative communities. In Designmatters, I0, pp. 64-68.

Manzini Ezio (20I5). Design, when everybody designs: An introduction to design for social innovation. Cambridge: MA: MIT Press.

Marsden Terry K., Sonnino Roberta (2012). Human Health and Wellbeing and the Sustainability of Urban-Regional Food Systems, Current Opinion. In Environmental Sustainability, 4(4), pp. 427-430.

Milgram Paul, Kishino Fumio (1994). A taxonomy of mixed reality visual displays. In IEICE TRANSACTIONS on Information and Systems, 77(12), pp. I $321-1329$. 
Montanari Massimo (2004). Il cibo come cultura. Bari: Laterza.

Morgan Nigel, Pritchard Annette, Pride Roger (a cura di). (2007). Destination branding. Oxford: Elsevier ButterworthHeinemann.

Parente Marina, Sedini Carla (a cura di). (2019). D4T design per i territori. Approcci, metodi, esperienze. Trento: List.

Riva Giuseppe (2019). Realtà Virtuali. Firenze: Giunti.

Simonelli Giuliano, Zurlo Francesco (2003). MEDesign Research. Exploiting resources in the Meditrerranean area: what is the role of design? In AA.W. Designing Designers: Design for a local global world. Milano: POLI.design, pp 89- I 0 I.

Villari Beatrice (20 I 3). Design, comunità, territori. Un approccio community centred per progettare relazioni, strategie e servizi. Milano: Libraccio Editore.

Author

Daniele Rossi, Università degli Studi di Camerino, daniele.rossi@unicam.it

To cite this chapter. Rossi Daniele (2020). Le Marche in tavola: Realtà Virtuale e Realtà Aumentata per il patrimonio alimentare/Le Marche in tavola: Virtual and Augmented Reality for food heritage. In Arena A., Arena M., Brandolino R.G., Colistra D., Ginex G., Mediati D., Nucifora S., Raffa P. (a cura di). Connettere. Un disegno per annodare e tessere. Atti del $42^{\circ}$ Convegno Internazionale dei Docenti delle Discipline della Rappresentazione/ Connecting. Drawing for weaving relationships. Proceedings of the 42th International Conference of Representation Disciplines Teachers. Milano: FrancoAngeli, pp. 3756-3773. 